\title{
Socio-Economic Profile of Farm Women in Potato Field, Kannauj District, Uttar Pradesh, India
}

\author{
Rashmee Yadav*, Amisha Kumari, Katyayni and Neelma Kunwar \\ Department of Extension Education, C.S.A. University of Agriculture and Technology, \\ Kanpur-208002 U.P., India \\ *Corresponding author
}

\begin{tabular}{|c|}
\hline Keywords \\
\hline $\begin{array}{l}\text { Potato crop, Socio- } \\
\text { economic, Solanum } \\
\text { tuberosum L. }\end{array}$ \\
\hline Article Info \\
\hline $\begin{array}{l}\text { Accepted: } \\
30 \text { March } 2018 \\
\text { Available Online: } \\
10 \text { April } 2018\end{array}$ \\
\hline
\end{tabular}

\section{Introduction}

Potato (Solanum tuberosum) originated in the highlands of South America, where it has been consumed for more than 8000 years. Spanish explorers brought the plant to Europe in the late $16^{\text {th }}$ century as a botanical curiosity. By the $19^{\text {th }}$ century it had spread throughout the continent, providing cheap and abundant food for the workers of the Industrial Revolution.
Potato was introduced in India in the early part of the $17^{\text {th }}$ century by the Portuguese. It was first cultivated in Surat on the West coast. From there it spread to other areas, like Goa, which were under Portuguese influence. In Goa, potato was called "Batata Surrata", pointing towards the likely introduction of Potato from Surat. As early as 1675, Fryer mentions Potato as one of the common garden crops after his survey of Karnataka. The 
spread of Potato to the Southern parts of the country was apparently quite rapid. Among vegetables, potato and its products are the most important items of consumption in the world including India. Potato is a major food crop, grown in more than 100 countries in the world. According to FAO (2008), Potato is consumed by more than one billion people in the world. It is a high quality vegetable cum food crop and used in preparing more than 100 types of recipes. The protein content of Potato has a high biological value than cereals and considered to be better than milk. Hence, Potato is supplementing meat and milk products by lowering energy intake and also by reducing food cost.

\section{Profile of the study area}

Kannauj District is an administrative district of Uttar Pradesh state in northern India, along the river Ganges. The historic town of Kannauj, northwest of Kanpur, is the administrative centre. The district was carved out of the Farrukhabad district on September 18 , 1997. Kannauj is located at $27.07^{\circ} \mathrm{N}$ $79.92^{\circ} \mathrm{E}$. It has an average elevation of 139 metres (456 feet). The Ganges is the main river of the district at the North East border of the district.

Kali River is at the northern border of the district while the Ishan River flows through the District. The climate of the district is characterized by a hot dry summer and a pleasant cold season. The average rainfall of the District is approximately $80 \mathrm{~cm}$. The district is bounded by the districts of Farrukhabad to the north, Hardoi to the northeast, Kanpur Nagar to the east, Kanpur Dehat to the southeast, Auraiya to the south, Etawah to the southwest, and Mainpuri to the west. The district is divided into three tehsils and seven development blocks. The district was split from Farrukhabad on September 18, 1997, and is part of Kanpur Division.

\section{Materials and Methods}

\section{Research design}

The research design is the plan, structure and strategy of investigations of answering the research question. It is the overall plan or blue print the researchers select to carry out their study. The design used in this study is descriptive design.

\section{Pilot study}

Prior to finally deciding the title of the project a pilot survey of the area was conducted. This gave the researcher an idea about the place of the study and nature of the samples that could be drawn along with the type of aspects and problems which could be explored out.

\section{Pre-testing of instruments}

Before collecting the necessary data from the finally selected sample of 300 farm women, 100 farm women were identified other than those included in the final sample. These 100 farm women were interviewed with the help of a structured interview schedule developed for collecting the data necessary for the present study. This helped the investigator in making necessary changes and modifications in the instrument to be finally used in their wordings and compositions.

\section{Results and Discussion}

\section{Age of respondents}

Table 1 reveals the distribution of respondents according to age group. 55.3 per cent of farm women belonged to age group 20 to 30 years with mean age 23 years and standard deviation (S.D.) 5 years, followed by 20.7 per cent of respondents who belonged to 30 to 40 years of age group with mean age 34 years and S.D. 4 years. 14.0 per cent of farm women belonged 
to age group 40 to 50 years with mean age 43 years and S.D. 4 years whereas, 10.0 per cent of respondents belonged to 50 years and above age group with mean age 54 years and S.D. 6 years.

\section{Literacy of respondents}

Table 2 shows the distribution of respondents according to education. 32.0 per cent of farm women were found to be illiterate in the study area, followed by 30.7 per cent of farm women who were educated up to middle level. 26.7 per cent of respondents were educated up to primary level, whereas, 7.3 per cent of farm women were educated up to high school. 2.3 per cent of respondents were educated up to graduate, while only 1.0 per cent respondents passed intermediate.

\section{Caste}

The table 3 shows the distribution of farm women according to caste. 45.7 per cent of farm women belonged to O.B.C. whereas, 32.6 per cent of respondents belonged to SC/ST category. 21.7 per cent of farm women belonged to general category in the study area.

\section{Occupation}

Table 4 reveals the distribution of respondents according to occupation. 49.0 per cent of respondents were engaged in agriculture in the study area whereas, 31.3 per cent of farm women were labour class. 12.0 per cent of farm women were engaged in business occupation, while only 7.7 per cent of farm women were found to be in service class.

\section{Annul income}

Table 5 indicates the distribution of farm women according to annual income. 41.7 per cent of respondents were earning Rs. 30,001 to Rs. 40,000 annually with mean income of Rs. 35872 and standard deviation Rs. 2730 whereas, 40.3 per cent of farm women were earning Rs. 20,000 to Rs. 30,000 annually with mean income of Rs. 23,148 and S.D. Rs. 3862. 14.3 per cent of farm women earned Rs. 40,001 to Rs. 50,000 annually with mean income of Rs. 46,650, while only 3.7 per cent of respondents earned Rs. 50,001 and above annually with mean income of Rs. 55,420 and standard deviation Rs. 2624.

\section{Marital status of respondents}

It is obvious from the table 6 reveals the distribution of farm women according to marital status. 41.0 per cent of farm women were found to be married in the study area, whereas, 35.3 per cent of farm women were either single or unmarried. Only 23.7 per cent of respondents were found to be widow.

Table.1 Distribution of farm women according to age group

\begin{tabular}{|c|l|c|c|c|}
\hline SI.No. & Age group (years) & Frequency & Per cent & Mean \pm S.D. \\
\hline 1. & $20-30$ & 166 & 55.3 & $23 \pm 5$ \\
\hline 2. & $30-40$ & 62 & 20.7 & $34 \pm 4$ \\
\hline 3. & $40-50$ & 42 & 14.0 & $43 \pm 4$ \\
\hline 4. & 50 and above & 30 & 10.0 & $54 \pm 6$ \\
\hline & Total & 300 & 100.0 & $28 \pm 6$ \\
\hline
\end{tabular}


Table.2 Distribution of farm women according to education

\begin{tabular}{|c|l|c|c|}
\hline Sl.No. & Education & Frequency & Per cent \\
\hline 1. & Illiterate & 96 & 32.0 \\
\hline 2. & Up to Primary & 80 & 26.7 \\
\hline 3. & Up to Middle & 92 & 30.7 \\
\hline 4. & High School & 22 & 7.3 \\
\hline 5. & Intermediate & 3 & 1.0 \\
\hline 6. & Graduation & 7 & 2.3 \\
\hline & Total & 300 & 100.0 \\
\hline
\end{tabular}

Table.3 Distribution of farm women according to caste

\begin{tabular}{|c|l|c|c|}
\hline Sl.No. & Caste & Frequency & Per cent \\
\hline 1. & General & 65 & 21.7 \\
\hline 2. & O.B.C. & 137 & 45.7 \\
\hline 3. & SC/ST & 98 & 32.6 \\
\hline & Total & 300 & 100.0 \\
\hline
\end{tabular}

Table.4 Distribution of farm women according to occupation

\begin{tabular}{|c|l|c|c|}
\hline Sl.No. & Occupation & Frequency & Per cent \\
\hline 1. & Agriculture & 147 & 49.0 \\
\hline 2. & Service & 23 & 7.7 \\
\hline 3. & Business & 36 & 12.0 \\
\hline 4. & Labour & 94 & 31.3 \\
\hline & Total & 300 & 100.0 \\
\hline
\end{tabular}

Table.5 Distribution of farm women according to annual income

\begin{tabular}{|c|l|c|c|c|}
\hline Sl.No. & Annual income & Frequency & Per cent & Mean \pm S.D. \\
\hline 1. & $20,000-30,000$ & 121 & 40.3 & $23148 \pm 3862$ \\
\hline 2. & $30,001-40,000$ & 125 & 41.7 & $35872 \pm 2730$ \\
\hline 3. & $40,001-50,000$ & 43 & 14.3 & $46650 \pm 3082$ \\
\hline 4. & 50,001 and above & 11 & 3.7 & $55420 \pm 2624$ \\
\hline & Total & 300 & 100.0 & $39296 \pm 3926$ \\
\hline
\end{tabular}

Table.6 Distribution of farm women according to marital status 
Table.7 Distribution of farm women according to land holding

\begin{tabular}{|c|l|c|c|c|}
\hline S..No. & Land holding & Frequency & Per cent & Mean \pm S.D. \\
\hline 1. & Landless & 174 & 58.0 & - \\
\hline 2. & Marginal & 102 & 34.0 & $1.5 \pm 0.6$ \\
\hline 3. & Small & 22 & 7.3 & $3.7 \pm 0.7$ \\
\hline 4. & Large & 2 & 0.7 & $5.6 \pm 0.9$ \\
\hline & Total & 300 & 100.0 & $2.4 \pm 0.8$ \\
\hline
\end{tabular}

Table.8 Distribution of farm women according to farm power and machinery

\begin{tabular}{|c|l|c|c|}
\hline S.No. & Particular & Frequency & Per cent \\
\hline 1. & Tractor & 8 & 2.7 \\
\hline 2. & Potato planter & 25 & 8.3 \\
\hline 3. & Potato digger & 48 & 16.0 \\
\hline 4. & Automatic potato planter & 5 & 1.7 \\
\hline 5. & Potato planter drip & 3 & 1.0 \\
\hline 6. & Tube well & 60 & 20.0 \\
\hline 7. & Cultivator & 40 & 13.3 \\
\hline 8. & Chaff cutter & 56 & 18.7 \\
\hline 9. & Sprayer & 39 & 13.0 \\
\hline 10. & Drought animal & 115 & 38.3 \\
\hline
\end{tabular}

Table.9 Distribution of farm women according to number of animals

\begin{tabular}{|c|l|c|c|}
\hline SI.No. & Particular & Frequency & Per cent \\
\hline 1. & Number of animals & 288 & 96.0 \\
\hline 2. & Number of milch animals & 208 & 69.3 \\
\hline
\end{tabular}

Table.10 Distribution of farm women according to type of house

\begin{tabular}{|c|l|c|c|}
\hline SI.No. & Type of house & Frequency & Per cent \\
\hline 1. & Kachcha & 144 & 48.0 \\
\hline 2. & Pucca & 34 & 11.3 \\
\hline 3. & Mixed & 122 & 40.7 \\
\hline & Total & 300 & 100.0 \\
\hline
\end{tabular}

Table.11 Distribution of farm women according to social participation

\begin{tabular}{|c|l|c|c|}
\hline Sl.No. & Organization & Frequency & Per cent \\
\hline 1. & Block Panchayat & 76 & 25.3 \\
\hline 2. & Block Cooperatives & 47 & 15.7 \\
\hline 3. & SHGs & 53 & 17.7 \\
\hline 4. & NGOs & 76 & 25.3 \\
\hline 5. & Mahila Mandal & 48 & 16.0 \\
\hline & Total & 300 & 100.0 \\
\hline
\end{tabular}




\section{Land holding}

The table 7 reveals the distribution of farm women according to land holding. Maximum 58.0 per cent of farm women were found to be landless farmers in the study area, followed by 34.0 per cent of respondents who had marginal land holding with mean 1.5 acres and standard deviation 0.6 acres. 7.3 per cent of farm women possessed small portion of land with mean 3.7 acres and S.D. 0.7 acres, while only 0.7 per cent of farm women had large land holding with mean 5.6 acres and standard deviation 0.9 acres.

\section{Farm power and machinery}

Table 8 shows the distribution of farm women according to farm power and machinery. 38.3 per cent of farm women had drought animals, followed by 20.0 per cent respondents who possessed a tube well.

18.7 per cent of farm women had a chaff cutter, while only 16.0 per cent of women had a potato digger. 13.3 per cent of women were having cultivator, 13.0 per cent had sprayer, 8.3 per cent of respondents had a potato planter, 2.7 per cent of farm women had a tractor and only 1.7 per cent of farm women possessed an automatic potato planter.

Those farmers who were involved in potato cultivation at commercial level, possessed potato planter $(8.3 \%)$, potato digger $(16.0 \%)$ and potato planter drip (1.0\%) as it reduced the labour cost and time involved in doing that particular activity.

\section{Number of animals (Table 9)}

It is evident from table 9 indicates the distribution of farm women according to animals possessed. 96.0 per cent of respondents had animal whereas, 69.3 per cent of farm women possessed milch animals.

\section{Type of house 10}

In table 10 shows the distribution of farm women according to type of house. 48.0 per cent of respondents possessed Kachcha house, whereas, 40.7 per cent of farm women lived in mixed house. Only 11.3 per cent of respondents had a pucca house in the study area. In villages it is seen that mostly villagers live in kachcha houses and pucca houses are only possessed by the upper caste and large farmers. 40.7 per cent of farmers lived in mixed type of houses as they believed that living in both kachcha and pucca house was part of their ritual.

\section{Social participation}

Table 11 shows the distribution of farm women according to social participation. 25.3 per cent of respondents participated in block Panchayat and NGOs respectively, while 17.7 per cent of farm women were either members or participated in SHGs and 16.0 per cent of farm women participated in Mahila Mandal in the study area. 15.7 per cent of farm women participated in block cooperative society in the study area.

\section{References}

Fakoya, E.O. and Omoare, A.M. (2014). Impending factors to value addition in the value chain of sweet potato in Osun State, Nigeria". Economic and Social Development: Book of Proceedings: 292-301. Varazdin: Varazdin Development and Entrepreneurship Agency

Jethi, R. (2008). "Participation of farm women in potato production". Indian Research Journal of Extension Education; 8(1):63-65.

Kubrevi, S.S. and Sofi, K.A. (2008). "Knowledge of farmers towards recommended practices of potato 
cultivation". Environment and Ecology. 26(4):1688-1690.

Peer, Q.J. A., Ahmad, N., Kaur, J., Chesti, M.

H., Ahmad, H. S., Bhat, A., and Bhat,
B. A. (2013). Study on economics of potato growing towards livelihood security. Afr. J. Agric. Res. 8(45): 56395644

\section{How to cite this article:}

Rashmee Yadav, Amisha Kumari, Katyayni and Neelma Kunwar. 2018. Socio-Economic Profile of Farm Women in Potato Field, Kannauj District, Uttar Pradesh, India. Int.J.Curr.Microbiol.App.Sci. 7(04): 3711-3717. doi: https://doi.org/10.20546/ijcmas.2018.704.417 